logians and pastors may be seen as particularly apt at a time when new initiatives in teaching and research in gerontology are getting under way in this country.

Christian Council on Ageing, Northamptonshire

\title{
Work and Retirement
}

\section{Chris Phillipson}

Malcolm H. Morrison, 'Work and Retirement in the Aging Society', Daedalus, 115 ( 1986 ), 269-294.

Malcolm Morrison's essay appears in a collection, sponsored by the Journal of the American Academy of Arts and Sciences, devoted to the theme of an Ageing Society. The focus, perhaps inevitably, is on the American scene, but there are some excellent individual contributions which deserve a wide readership.

Morrison's essay attempts to draw conclusions from three principle areas of research and debate: first, the findings from research on attitudes towards retirement; secondly, perspectives on the history of retirement; thirdly, discussions on the economic consequences of retirement policies.

On the first area, Morrison suggests contradictory forces are at work in public attitudes and perceptions about retirement. On the one hand, there appears to be increasing acceptance of retirement as a social institution; on the other hand, significant numbers of retirees still feel deprived of significant roles which allow them to maintain a presence in society.

The historical research, according to Morrison, points to how retirement became institutionalised through policies aimed at increasing job security, replacing 'energetic' for 'worn-out' employees, and providing income security for superannuated workers. Ultimately, it was to be an economic crisis (in the r 930 ) which gave the decisive push to the emergence of this social institution.

Thirdly, there is the question of the implications of reduced labourforce participation. Here, the author errs on the side of the pessimists: older people, he suggests, are expensive (consuming, at present, $30 \%$ of the annual federal budget) and non-productive (both in waged and unwaged terms). In the long term, he argues, this growth in the non-waged sector cannot be sustained. Morrison draws upon two main arguments to strengthen his case. First, retirement policies were developed at a time when there were relatively few older people. This situation has clearly changed and with the current emphasis on early and complete retirement, significant economic problems could develop 
in the future. Secondly, Morrison suggests that societal values are beginning to change. He argues that 'Many older workers are already continuing productive participation in society, demonstrating not only that they can still maintain their former roles, but that they can create new roles as well - roles that involve both direct participation in the economy and voluntary activities. This, combined with great improvement in the economic status of the old, is changing social views of aging as a period of loss, and debilitation. Older age is becoming more highly valued as a period during which a continuing contribution to society is possible.'

Morrison concludes that older people must be brought back into productive roles: $(a)$ if we are to avoid inter-generational tension; $(b)$ if we are to resolve what will be a crushing economic burden; $(c)$ if we are to acknowledge the expressed desires of older people themselves.

The solution? We need to reconceptualise work and retirement and develop life-long education and training: 'Only then will the definition of retirement gradually change, will public and private policies be modified to bring about a society that offers innovative alternatives for work and retirement, and will there be major enhancement of the roles and responsibilities of older persons.'

\section{Comment}

At one level, it is difficult to disagree with many of Morrison's arguments, but (as with many pessimists in this field) he greatly overstates his case. First, he exaggerates the extent of resistance to retirement. It is noticeable here that he fails to draw upon the various longitudinal research studies of the retirement experience, these suggesting that poor health and low income are more decisive in their impact than the absence of work itself. ${ }^{1}$ Secondly, Morrison does not actually provide evidence for inter-generational tension over obligations towards older people. Interestingly, this was a point raised by the Thatcher Government in justifying reform of the state earnings-related pension scheme (SERPS). There was no evidence given here either that younger and middle-aged people were questioning the extent of their support. Indeed, studies from Taylor-Gooby and others would suggest considerable public commitment to increasing the standards of living in old age. ${ }^{2}$ Thirdly, Morrison assumes that current retirement trends will create a major economic burden by the middle of the next century. Again, this approach does not appear to be grounded in any rigorous assessment of the facts: we are told nothing about trends in economic growth, labour productivity, or unemployment (particularly amongst 
blacks, women and younger people). Finally, and most damaging of all, Morrison makes an assumption that older people are non-productive both in the sense of remunerative employment and volunteer roles. The former is undeniable; the latter is surely, however, what older people are doing in droves, and in ways which are often vital to neighbourhood and community life.

Finally, it would be good to have life-long education and training. But we should draw lessons from the historical research. Older people are sometimes trained for work under capitalism, but the timing and opportunities are rarely aspects over which they have very much control. How to give people this control over their occupational lives is a critical issue for those concerned with work and retirement issues.

\section{NOTES}

I See, for example, Parnes, H. et al., Retirement Among American Men, Lexington Books, Mass., 1985 .

2 Taylor-Gooby, P., Public Opinion, Ideology and State Welfare, RKP, London, 1985.

Linda Evans, David Ekerdt and Raymond Bosse, 'Proximity of Retirement and Anticipatory Involvement: Findings from the Normative Aging Study', fournal of Gerontology, 4o (1985), 368-374.

The transition from work to retirement continues to be an important focus for gerontological research. In particular, for the last $10-15$ years there has been a keen debate about the character of the retirement process and the extent to which this includes a period of anticipatory socialisation. Atchley, for example, suggests that pre-retirees utilise a range of methods, ranging from retirement courses to informal discussions with friends and family, to assess their future life in retirement. Other research has explored the way in which retirement attitudes, job characteristics and personal resources, influence positive of negative pre-retirement attitudes.

The purpose of the study by Evans et al. was to investigate the pre-retirement process in more detail, examining, first, ' the relationship between retirement proximity and pre-retirement involvement, and secondly, the association between retirement-orientated activities and three other sets of variables: attitude toward retirement, job characteristics and personal resources.'

The sample was drawn from participants in the Normative Aging Study (NAS) of the Veterans Administration in Boston. The NAS is an inter-disciplinary panel study of over 2000 men, the main purpose 
of which is a study of the non-pathological aspects of ageing. The men in the study reported here comprise all those who respond to a mail questionnaire and who anticipated retiring within the next 15 years. This produced a total of 8 I 6 men who were evenly distributed over the I 5 year pre-retirement period. The mean age of the group was 54.8 years and $60 \%$ held white-collar jobs (this reflected the higher social class levels of the panel group than the general population from which it was drawn).

For the dependent variable the authors constructed a pre-retirement involvement scale, based on how often the pre-retiree had talked with his wife, his relatives, his close friends, or people on the job and/or read articles about retirement. The independent variables included in the study were proximity to retirement, attitudes towards retirement, job characteristics and personal resources. The analysis proceeded in two stages: first, an examination of the relationship between proximity to retirement and pre-retirement involvement; secondly, a study of the relationship between involvement and the independent variables listed above.

The results of the study suggested, as might be predicted, that those participants closest to retirement showed the highest levels of retirementorientated behaviour. However, less predictable was the finding that such behaviour was still encountered, albeit at a lower level, even amongst those with very negative views about leaving work.

Multiple regression techniques were used to identify some of the influences affecting the individual's appruach to retirement. The results underlined the importance of attitudinal factors in boosting the extent of pre-retirement involvement. However, personal resources and job characteristics were also important. In the case of the former, the relevant variables were: having had a retired friend, placing greater importance on pastimes and hobbies, feeling that one's pension was adequate, and a having serious health problem.

\section{Comment}

This study suggests that a process of formal or informal retirement preparation may take place some years before the actual event. Nearness to retirement is clearly important in stimulating involvement in this process. The useful finding, however, from this research is that involvement occurs even amongst those with pronounced negative views about leaving work. This challenges the idea that such feelings can undermine attempts to prepare for retirement. Moreover, taken as a whole, the data confirms (along with other studies) that a pre- 
496 Chris Phillipson

retirement phase does exist; it remains less clear, however, about, how the dynamics of this phase influence behaviour and adaptation in retirement itself.

Department of Adult and Continuing Education, University of Keele 